\title{
A Decision Making Tool for Selection of LSPs
}

\author{
Aicha Aguezzoul ${ }^{1} \&$ Gilles Paché $^{2}$ \\ ${ }^{1}$ CEREFIGE, Lorraine University, Metz, France \\ ${ }^{2}$ CRET-LOG, Aix-Marseille University, Aix-en-Provence, France \\ Correspondence: Professor Gilles Paché, CRET-LOG, 413 Avenue Gaston Berger, 13625 Aix-en-Provence \\ Cedex, France. E-mail: gilles.pache@univ-amu.fr
}

Received: February 22, 2018

doi:10.5539/ijbm.v13n5p95

\begin{abstract}
This research note aims to propose a multiple criteria decision making (MCDM) based on ELECTRE method to solve the logistics service providers (LSPs) selection problem. In the contemporary global market, this selection represents a strategic process and a complex issue, as it involves various qualitative and quantitative criteria as well as decisions. The proposed model consists of two phases: (1) a survey of French firms was carried out so as to identify the factors that should be considered in the LSPs selection decision; (2) an application of the model, as well as its comparison with the weighted sum, were conducted. The approach uses criteria that are important for the firms that participated to the survey. The results indicate that the ELECTRE method suggests a better ranking of the LSPs than the weighted sum, initially used in the case study. The proposed MCDM model can provide the guidelines and directions for the decision makers to effectively choose LSPs in the current competitive environment. In addition, this study fills a gap in the literature on LSPs selection problem, where MCDM methods are seldom used.
\end{abstract}

Keywords: decision making, ELECTRE method, logistics service providers, selection process

\section{Introduction}

Among the most significant mutations in the structuration mode of contemporary supply chains, the emergence, then the consolidation of logistics service providers (LSPs) occupies a privileged place. For a long time limited to basic activities and techniques of transport and storage, which create little added value, "world-class" LSPs such as XPO Logistics, Kuehne+Nagel, Geodis and DHL Supply Chain are now able to carry out operations relating them to real assemblers. The rise of LSP results directly from the logistics outsourcing process driven by shippers for more than three decades. This reality is now well known and widely addressed in the literature (Cahill, 2007; Wallenburg, 2009; Fulconis et al., 2011; Saglietto \& Cézanne, 2017). Indeed, a growing number of industrial and commercial companies have outsourced their logistics activities by entrusting them to specialized partners in order to focus on their core business. The growing interest in logistics outsourcing is being facilitated by many other factors such as cost reduction thanks to the economies of scale generated by the LSPs or by a release of capital immobilized, a transformation of fixed costs into variable costs, thus allowing to concentrate its own resources (financial, human, etc.) on its production and on its own know-how, an increase in flexibility deriving from knowledge of markets and products, but also privileged access to skills and professionalism of LSPs.

Several research studies point out that in many industries, the use of LSPs has grown significantly in the last twenty years. As early as the mid-2000s, Lieb and Bentz (2005) report that about $60 \%$ of the Fortune 500 companies in US reported having at least one LSP contract and that the market for these LSPs has been steadily increasing, which has been confirmed since then (Fulconis et al., 2011). More recently, Li et al. (2012) indicate that in Japan, about $70 \%$ of firms outsource their main logistics operations, and in US, about $42 \%$ of firms outsource some or all of their logistics operations. This explains the explosion of studies conducted on LSPs, generally of empirical and exploratory type, that focus on the following four research themes: (1) reasons, benefits and risks of the logistics outsourcing decision (Aktas et al., 2011; Tsai et al., 2012; Lu et al., 2014; König \& Spinler, 2016; Gómez et al., 2017); (2) modeling, planning and evaluation of the integrated logistics network for LSPs (Mahmoudzadeh et al., 2013; Jothimani \& Sarmah, 2014; Suyabatmaz et al., 2014); (3) analysis of LSP/shipper relationships (Hofenk et al., 2011; Handley \& Benton, 2012; Abdul Rahman et al., 
2014; Muhindo et al., 2014; Sallnäs, 2016; Bask et al., 2018); and (4) LSP selection process (Aguezzoul, 2014; Tan et al., 2014; Alkhatib et al., 2015; Yayla et al., 2015; Kishore \& Padmanabhan, 2016).

This research note is particularly interested in the problem of LSP selection and in the application, to face it, of multi-criteria method ELECTRE. Such a choice is explained by the proven importance of supplier selection process theme in the industrial marketing literature since the 1970s (De Boer et al., 2001; Hsu et al., 2006), but without a real deepening of conclusions obtained is suggested at LSP selection level. In other words, it is possible to identify today a relative conceptual gap that we wish to fill in part. For this, we will rely on a real case from the French industrial world, comparing the results of the ELECTRE method to those of the method initially used in the case treated. In a first step, we will conduct a brief literature review on LSP selection issue. The proposed method will be described in a second step, before applying it to the aforementioned context in a third step. The research note will end with a conclusion suggesting complementary research orientations in logistics and in supply chain management.

\section{The LSP Selection Problem}

For a shipper, logistics outsourcing is to entrust a LSP all or part of the execution, and sometimes the design, of its logistics activities, previously provided internally, with possibly a transfer of material and human resources. This strategic and complex decision allows the company to refocus on its core business, whether the communication advertising, the new products development, or the components assembly. LSPs can carry out logistics activities of their customers (fully or partially), may or may not own warehouses and means of transport, knowing that many of them claim an increasingly strong global presence. As underlined by Boonpattarakan (2012), the LSP's first priority level in building competitive capabilities is then based on providing varying services and offering attractive prices. To achieve effective integration and coordination of supply chains, the most powerful LSPs have expanded their service offering by evolving from traditional or basic services (transport, warehousing) to high value-added services (co-manufacturing, co-packing, information technology, etc.) (Lai et al., 2004; Trentin, 2011; Fulconis et al., 2016; Marchet et al., 2017). Table 1 provides a list of activities that shippers traditionally associate with LSPs (Aguezzoul, 2014), while Figure 1 represents the different steps of logistics services evolution since the 1980s, from basic services to value-added services.

Table 1. Activities associated with LSPs

\begin{tabular}{cl}
\hline Logistics processes & \multicolumn{1}{c}{ Activities } \\
\hline \multirow{2}{*}{ Transportation } & $\begin{array}{l}\text { Road rail air sea, intermodality management, shipping, forwarding, package } \\
\text { express carrier, customs brokering, (de) consolidation, perishable/hazardous } \\
\text { goods management, freight bill payment/audit. }\end{array}$ \\
Outbound (distribution) & $\begin{array}{l}\text { Merge in transit, order fulfilment/processing, picking, sorting, dispatching, } \\
\text { post-production configuration, installation of products at the customer's site. }\end{array}$ \\
& $\begin{array}{l}\text { Storage, receiving, cross docking, (de) consolidation, perishable/hazardous } \\
\text { goods. }\end{array}$ \\
Warehousing & $\begin{array}{l}\text { Forecasting, slotting/lay out design, location analysis, storage/retrieval } \\
\text { management. }\end{array}$ \\
& $\begin{array}{l}\text { Design, labelling, assembly/packaging, palletizing. } \\
\text { Pallets flows management, recycling, reuse, remanufacturing disposal } \\
\text { Packaging }\end{array}$ \\
Reverse logistics & management, repair, testing/products serving, return shipment management. \\
\hline
\end{tabular}

Source: Aguezzoul (2014).

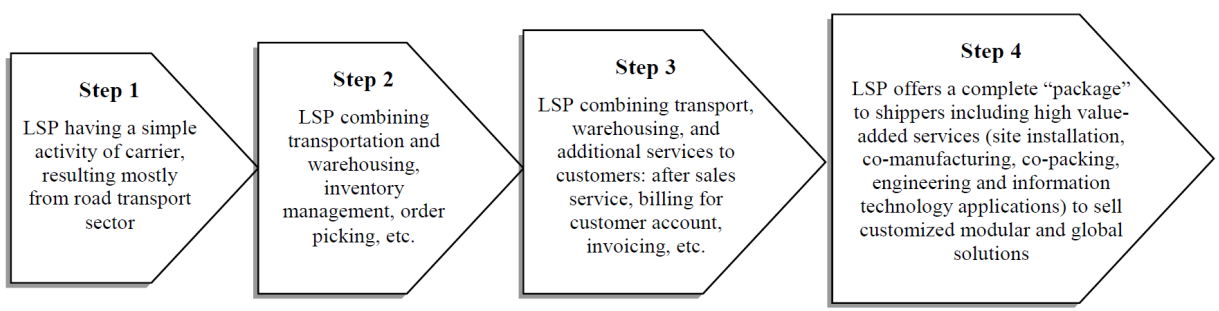

Figure 1. Evolution of logistics services in four steps 
Once the decision to work with a LSP is made by a shipper, the next step is to determine the best LSP according to different eligibility criteria. Therefore, the selection of a performant set of LSPs that can meet the loader customer needs becomes a decision of prime importance in the context of a dyadic relationship that is to govern more effectively. This decision is impacted by several factors that are generally contradictory to each other, such as price, service quality and reliability, range of services offered, technology mobilized, reputation in the market, etc. In a context of globalization and globalization of trade, which underlines the crucial question of optimization models for logistics nodes system layouts (Zhang \& Li, 2009), new factors must be taken into account, such as geographical coverage, cultural adequacy to target markets, environmental aspects, security of flows, etc. The importance of social links between decision makers, both at the shipper and at the LSP, is also an important dimension, although largely underestimated so far in the literature.

Several empirical studies, of an exploratory nature, on the process of LSP selection and evaluation performance have appeared in the academic literature to emphasize the strategic importance of the problem posed since the seminal works of McGinnis et al. (1995) and Menon et al. (1998). These studies identify several criteria used by companies in this process. The detailed meta-analysis conducted by Aguezzoul (2014) of 67 articles published during the 1994-2013 period, in international reference journals in logistics and SCM, identified 11 main criteria, as well as their attributes (sub-criteria). Table 2 presents all the attributes and definitions associated with each of these criteria. In order to implement a set of criteria in the LSP selection process, it is of course necessary to use appropriate tools and techniques, such as the compensatory and non-compensatory models used for example in BtoB marketing.

Table 2. Summary of evaluating criteria

\begin{tabular}{|c|c|}
\hline Criteria & Definition \\
\hline Cost & $\begin{array}{l}\text { It refers to the total cost of logistics outsourcing. Its related attributes include price, cost reduction, low cost } \\
\text { distribution, expected leasing cost, operation cost, warehousing cost, and cost savings. }\end{array}$ \\
\hline Relationship & $\begin{array}{l}\text { It includes shared risks and rewards, ensure cooperation between the user and the LSP. It also helps in } \\
\text { controlling the LSP opportunistic behaviour. Reliability, truth, dependence, alliance, compatibility, reciprocity } \\
\text { are among its attributes. }\end{array}$ \\
\hline Services & $\begin{array}{l}\text { It is related to attributes such as breadth of services, characterization/specialization of services, variety of } \\
\text { available services, pre-sale/post-sale customer services, and value-added services. }\end{array}$ \\
\hline Quality & $\begin{array}{l}\text { Quality of the LSP includes many aspects such as, commitment to continuous improvement, SQAS/ISO } \\
\text { standards environment issues, and risk management. }\end{array}$ \\
\hline $\begin{array}{l}\text { Information \& } \\
\text { equipment system }\end{array}$ & $\begin{array}{l}\text { It corresponds to physical equipment and information system that has a LSP to facilitate communication and } \\
\text { execution of logistics operations of its customers. It's related to attributes such as EDI, tracking/tracing, technology } \\
\text { capabilities, information accessibility, availability of computer network, informatization level, technical/engineering } \\
\text { capability, materials handling equipment, and information security. }\end{array}$ \\
\hline Flexibility & $\begin{array}{l}\text { Ability to adapt to changing customers requirements and circumstances. Its attributes include ability to meet future } \\
\text { requirement, capacity to accommodate and grow the client's business, system flexibility index, responsiveness to } \\
\text { target market or service requests, capability to handle specific business requirements, and time response capability. }\end{array}$ \\
\hline Delivery & $\begin{array}{l}\text { It is represented by attributes such as: time, on-time performance, on time shipment and deliveries, delivery } \\
\text { speed, accuracy of transit/delivery time, shipment delivery, and on-time delivery rate. }\end{array}$ \\
\hline Professionalism & $\begin{array}{l}\text { LSP exhibit sound knowledge of services in the industry and display punctuality and courtesy in the way they } \\
\text { interact and present to the customers. It is characterized by attributes such as expertise, competence, and } \\
\text { experience. }\end{array}$ \\
\hline Financial position & $\begin{array}{l}\text { A sound financial performance of the LSP ensures continuity of service and regular upgrading of the } \\
\text { equipments and services, which are used in logistics operations. }\end{array}$ \\
\hline Location & $\begin{array}{l}\text { It is related to attributes such as distribution coverage, geographical specialization and coverage, international } \\
\text { scope, market coverage, shipment destinations, and distance. }\end{array}$ \\
\hline Reputation & $\begin{array}{l}\text { It refers to the opinion of the customers about how good are the LSP in satisfying their needs. This is more } \\
\text { relevant in the initial screening of LSP. }\end{array}$ \\
\hline
\end{tabular}

Source: Aguezzoul (2014).

The main approaches identified in the literature to solve the LSP selection problem have been classified by Aguezzoul (2014) in five categories: (1) multi-criteria decision making (MCDM); (2) statistical approaches; (3) artificial intelligence; (4) mathematical programming; and (5) hybrid methods. The choice of one of the methods depends on the criterion character (qualitative, quantitative), the outsourced activity, and the more or less broad 
set of competing LSPs. At the end, if the different methods help in decision making about the selection of best performing LSPs on the basis of the considered criteria, their limits are now recognized. Thus, the implementation of the statistical approaches requires a collection of measurable quantitative data from the beginning of the study, while artificial intelligence methods are used to model knowledge rather than data. The strength of MCDM methods is to present themselves as effective alternatives to methods of classic optimization such as mathematical programming, based on the definition of a single function, often expressed in economic (monetary) terms and which reflects the consideration of several criteria, often immeasurable (Pourjavad \& Shirouyehzad, 2011; Raut et al., 2018). More generally, as noted by Fenies (2011), decision support in the logistics context is now at the crossroads, as far as any modeling approach must simultaneously integrate algorithmic and systemic complexities of the problem posed, here LSP selection.

\section{ELECTRE I: A Robust Multi-Criteria Decision Approach}

Among MCDM techniques, outranking methods remain however rarely used in Management Sciences, and are among the most robust. The most well-known of these is ELECTRE (ELimination Et Choix Traduisant la REalite [elimination and choice expressing the reality]) method, originated in France in the mid-1960s, under the impetus of Bernard Roy studies (Roy, 1968). It is a global evaluation method that attempts to classify a number of described alternatives according to a number of criteria (see Figure 2). As noted by David and Damart (2011), we can speak of a real conceptual and epistemological leap made by Bernard Roy, since it is then for him that researchers accept the "the approximately true" by taking their distance with "the exactly wrong". Given its power, the ELECTRE method will be successfully applied in several areas of great diversity such as equipment maintenance, energy planning in a supply chain, production units implantation, business acquisition or route selection for cargo transportation (Sevkli, 2010; Haurant et al., 2011; Lazzolino et al., 2012; Botti \& Peypoch, 2013; Ishizaka \& Nemery, 2014; Yücel \& Görener, 2016; Wang \& Yeo, 2018).

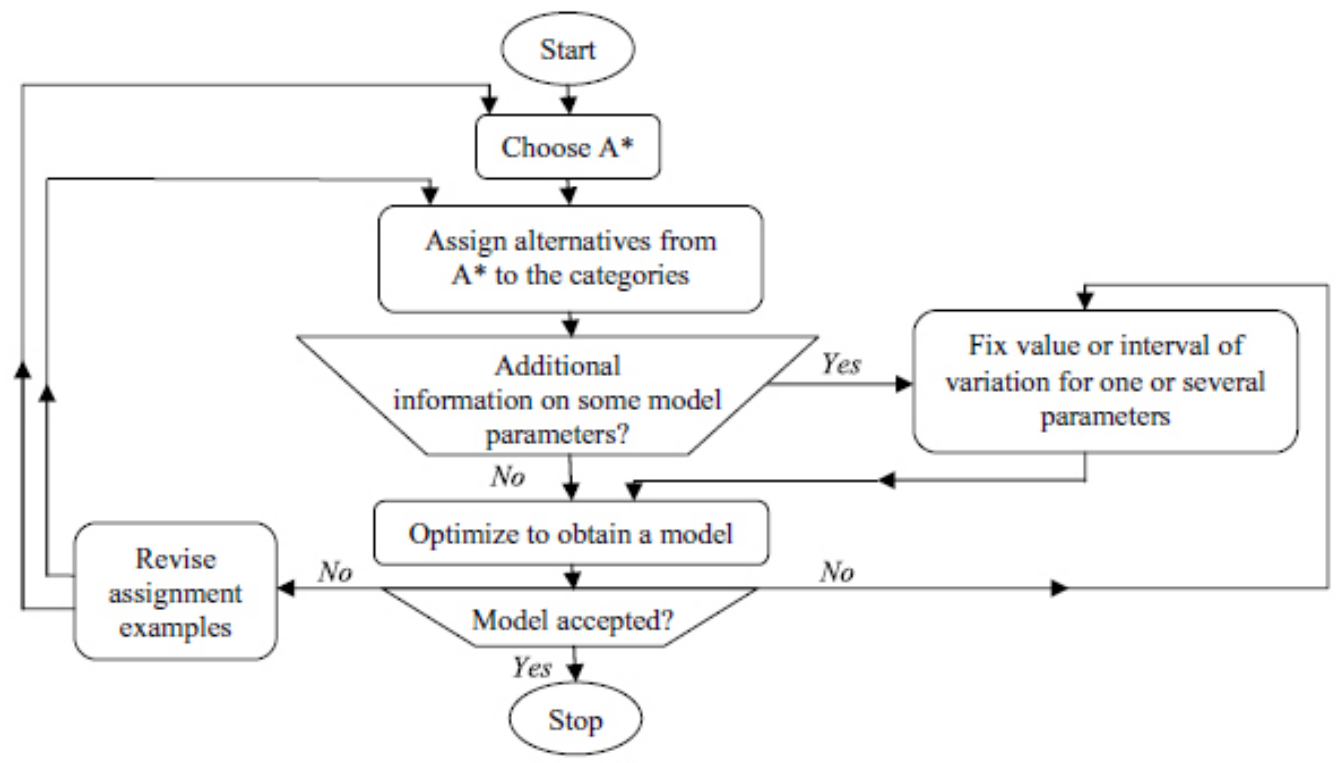

Figure 2. The ELECTRE method general scheme

Source: Adapted from Mousseau et al. (2000).

Hatami-Marbini and Tavana (2011), Mukherjee (2017) and Bianchini (2018) indicate in a general way that there is no optimal method for solving a MCDM problem, and the numerical comparison is insufficient to determine the most appropriate method for decision making. However, one of the ELECTRE method advantages is that, on the one hand, a poor performance on one criterion cannot be offset by good performances on other criteria, and on the other hand, the mechanism of solving a problem is not as extreme as purely non-compensatory methods, as encountered in BtoB marketing. In addition, Figueira et al. (2013) point out that research studies on ELECTRE method are still evolving, thanks to its new application fields, its new methodological and theoretical developments, as well as its implementations in user-friendly software. The recent study of Govindan and Brandt Jepsen (2016) reinforces such a finding. 
In the present research note, ELECTRE I method is specifically used to analyze a LSP selection process by a shipper, whereas it is rather AHP methods that are extensively used in literature (Vijayvargiya \& Dey, 2010; Ravi, 2011; Haldar et al., 2017; Jain \& Khan, 2017; Ecer, 2018). In addition to its advantages mentioned above, the decision to use ELECTRE I is due to its easy application, its flexibility, and its ability to identify the best solutions by specifying the preference order to multiple actions (Rogers et al., 2000), in accordance with the ELECTRE method general scheme (see Figure 2). Moreover, few academic studies have proposed the use of this method, first and foremost, is the contribution of Almeida (2007), which remains however, limited to the sole evaluation of transportation services outsourcing according to cost, delivery time and reliability criteria. The tool proposed in our research note allows the user to go further by selecting the LSPs according to a wide range of services offered, such as transport, warehousing, order picking, terminal assembly, reverse logistics, etc., which corresponds to the most advanced phase of logistics service evolution (Fulconis et al., 2011).

ELECTRE I is the first outranking method, originally developed by Roy (1968), as indicated previously. The outranking methods are particularly suitable for problems resolution such as LSP selection because of their capacity to deal with both qualitative and quantitative criteria, to manage compensatory effects, and to understand relationships between criteria (Roy \& Vincke, 1981). ELECTRE I method has been developed to determine a preference order among a discrete set of alternatives relative to a set of criteria by comparisons two to two of these alternatives. The preference is modeled using binary outranking relationships $S$, whose meaning is "at least as good as". Thus, considering two actions $X$ and $Y$, four situations may occur:

(i) $X S Y$ and not $Y S X$, i.e., $X$ is strictly preferred to $Y$;

(ii) $Y S X$ and not $X S Y$, i.e., $Y$ is strictly preferred to $X$;

(iii) $X S Y$ and $Y S X$, i.e., $X$ is indifferent to $Y$;

(iv) Not $X S Y$ and not $Y S X$, i.e., $X$ is incomparable to $Y$.

We note that the incomparability preference is a useful relationship to take into account situations in which decision makers are unable to compare two actions, given their limited rationality. According to ELECTRE I method, given two actions $X$ and $Y$, an outranking relation is based on two major concepts: concordance and discordance, defined as follows: (1) concordance concept: for an outranking $X S Y$ to be validated, a sufficient majority of criteria should be in favor of this assertion; and (2) non-discordance concept: when the concordance condition holds, none of the criteria in the minority should oppose too strongly to the assertion $X S Y$. These two conditions must be fulfilled for validating the assertion $X S Y$.

\section{A Case Study in the French Context}

We will take consider the data of a survey conducted in 2016, with a sample of 50 French industrial companies using LSPs. For data collection, three approaches were used: mail, telephone and e-mail. The mail and the e-mail include a cover letter and a questionnaire, and were addressed to logistics managers and decision makers of the companies. We have also conducted an in-depth phone interviews using the questionnaire as a guideline. The questionnaire focused on the following main points: (1) logistics activities outsourced; (2) most used LSPs; (3) LSP selection criteria; (4) LSP selection methods used; and (5) types of relationships with LSPs. 50 questionnaires were sent, to which 20 completed replies have been received, representing a response rate of $40 \%$. The information thus collected will be stored in a database, which will be exploited by Visual Basic type computer program (VB) that we have developed. The VB tool is very user-friendly, and easily to use. The inputs of our application are the criteria weights and the thresholds of concordance and discordance; while the outputs consist of the performance table, the concordance and discordance matrices, and the final selection of LSPs.

The nine LSPs generally used (and evaluated) by these companies are well-known operators, which are end up in the "Top 50" of European LSPs. In the following of the article and for confidentiality reasons, we name these nine LSPs in a random order, LSP1 to LSP9. To illustrate the method application, we present the case of one of the companies that participated in the survey. Thus, each of the nine LSPs is evaluated according to three criteria, each defined by a set of sub-criteria, namely: (1) Geographic coverage: France, North Africa and East Asia; (2) Services offered: international transit, intermodal transport, inventory control, and after sales service; and (3) Quality: TQM and logistics audit. The weights of $45 \%, 30 \%$ and $25 \%$ are respectively associated to criteria. These latter are evaluated on a scale from 0 (not important at all) to 7 (extremely important). It is thus possible to obtain the performance matrix indicated in Table 3. By fixing concordance and discordance thresholds at 0.75 and 0.1 respectively, the final result of ELECTRE I as well as that of the weighted sum appear in Table 4. 
Table 3. Performance matrix

\begin{tabular}{|c|c|c|c|}
\hline & Geographic coverage & Services offered & Quality \\
\hline Weight & $45 \%$ & $\mathbf{3 0} \%$ & $25 \%$ \\
\hline LSP1 & 2 & 4 & 0 \\
\hline LSP2 & 4 & 5 & 0 \\
\hline LSP3 & 0 & 5 & 5 \\
\hline LSP4 & 2 & 4 & 0 \\
\hline LSP5 & 2 & 7 & 0 \\
\hline LSP6 & 4 & 4 & 0 \\
\hline LSP7 & 0 & 6 & 5 \\
\hline LSP8 & 2 & 5 & 0 \\
\hline LSP9 & 0 & 5 & 5 \\
\hline
\end{tabular}

The VB tool provides the list of LSPs to be selected by ELECTRE I method as indicated in shaded boxes in Table 4. These LSPs are LSP2 and LSP5. We also compare this result with their classification according to the score obtained by weighting method. Table 4 shows that the selection of LSP2 is consistent in both methods. LSP7 and LSP6, ranked respectively in second and fourth position, have not been selected by the ELECTRE I method because they are dominated by other LSPs on certain criteria not highlighted with weighted sum method. It is thus possible to note that ELECTRE I method allows to identify the subset of LSPs offering the best possible compromise on the basis of criteria considered. This result also depends on the criteria weights or ratings corresponding to the importance that the decision maker assigns to each criterion. The proposed tool makes it possible to carry out a sensitivity analysis by varying the main factors that can influence LSP selection decision such as criteria weights, and concordance and disconcordance indices that characterize the outranking relationships between the criteria.

Table 4. Result of ELECTRE vs. weighted sum

\begin{tabular}{ccc}
\hline Ranking & Weighted sum & ELECTRE I \\
\hline 1 & 3,30 & P2 \\
2 & 3,05 & P7 \\
3 & 3,00 & P5 \\
4 & 3,00 & P3 \\
5 & 2,75 & P9 \\
6 & 2,75 & P8 \\
7 & 2,40 & P1 \\
8 & 2,10 & P4 \\
9 & 2,10 & \\
\hline
\end{tabular}

The results obtained open up major perspectives. Previous research in LSP selection has strongly emphasized the importance of implementing multi-criteria tools in the decision taken by the shipper. The MCDM method of ELECTRE I type proposed in this research note makes it possible to meet such a need since, on the one hand, it clearly falls under the suppliers (of logistics services) selection problem, and on the other hand, it offers to any company producing goods or services, the opportunity to select a powerful set of partners via several criteria of different nature. The criteria considered in such engineering approaches are not just from economic rationality, based on minimizing costs, but can also refer to environmental and social/societal aspects, whose centrality is now emphasized in the current context of sustainable development; this is the case of reverse logistics in which LSPs play an increasingly important role, as indicated in the academic literature (Min \& Ko, 2008; Colicchia et al., 2013; Muhindo et al., 2014; Guarnieri et al., 2015; Centobelli et al., 2017; Li et al., 2018).

\section{Conclusion}

This research note has analyzed the LSP selection problem by making a theoretical and managerial contribution related to the application of the outranking method ELECTRE I. A numerical example, based on a real case, made it possible to illustrate the proposed method, comparing it to weighted sum method initially mobilized. For ease of use, this method has been developed and implemented with Visual Basic software (VB). Furthermore, the tool seems flexible enough to integrate additional criteria, as required by the decision maker, the competitive environment and the organizational structure of the company (place of logistics activities in decision making 
system). On a theoretical level, the study conducted fills in part a gap identified in the literature on LSP selection problem, for which MCDM methods are rarely used. The impact is directly operational since the proposed tool provides an actionable approach for shippers who try, day after day, to streamline and efficiently manage their supply chain through extensive outsourcing of logistics activities to LSPs.

Regarding suggestions for research avenues, it would be interesting to deduce the weights assigned to different criteria, using methods such as AHP, ANP or QFD, rather than leaving a subjective choice into the hands of a decision maker with a bounded rationality (Fenies, 2011). Take into account the uncertain and imprecise nature of these weights, but also of the amplitudes of criteria scales and the tolerance thresholds of concordance and disconcordance indices, also opens exciting prospects for research in logistics and SCM. The present investigation being limited to a comparison of our approach with a simple method (the weighted sum), it would undoubtedly prove opportune to explore in parallel PROMETHEE or VIKOR methods, which also falls of alternatives selection issue. Finally, the results presented would benefit from confrontation to studies conducted in different economic and social contexts, thus allowing working for a cross-cultural approach of LSP selection modes.

\section{Acknowledgements}

The authors would like to thank Professor Wesley J. Johnston (Georgia State University) and two anonymous reviewers of the International Journal of Business \& Management for their helpful and constructive comments that contributed to improve the final version of the research note.

\section{References}

Abdul Rahman, N., Melewar, T., \& Sharif, A. (2014). The establishment of industrial branding through dyadic logistics partnership success (LPS): the case of the Malaysian automotive and logistics industry. Industrial Marketing Management, 43(1), 67-76. https://doi.org/10.1016/j.indmarman.2013.09.003

Aguezzoul, A. (2014). Third-party logistics selection problem: A literature review on criteria and methods. Omega, 49(C), 69-78. https://doi.org/10.1016/j.omega.2014.05.009

Aktas, E., Agaran, B., Ulengin, F., \& Onsel, S. (2011). The use of outsourcing logistics activities: the case of Turkey. Transportation Research Part C: Emerging Technologies, 19(5), 833-852. https://doi.org/10.1016/j.trc.2011.02.005

Alkhatib, S., Darlington, R., Yang, Z., \& Nguyen, T. (2015). A novel technique for evaluating and selecting logistics service providers based on the logistics resource view. Expert Systems with Applications, 42(20), 6976-6989. https://doi.org/10.1016/j.eswa.2015.05.010

Almeida, A. (2007). Multi-criteria decision model for outsourcing contracts selection based on utility function and ELECTRE method. Computers \& Operations Research, 34(12), 569-3574. https://doi.org/10.1016/j.cor.2006.01.003

Bask, A., Rajahonka, M., Laari, S., Solakivi, T., Töyli, J., \& Ojala, L. (2018). Environmental sustainability in shipper-LSP relationships. Journal of Cleaner Production, 172, 2986-2998. https://doi.org/10.1016/j.jclepro.2017.11.112

Bianchini, A. (2018). 3PL provider selection by AHP and TOPSIS methodology. Benchmarking: An International Journal, 25(1), 235-252. https://doi.org/10.1108/BIJ-08-2016-0125

Boonpattarakan, A. (2012). Competitive capabilities of Thai logistics industry: effects on corporate image and performance. International Journal of Business \& Management, 7(5), 19-30. https://doi.org/10.5539/ijbm.v7n5p19

Botti, L., \& Peypoch, N. (2013). Multi-criteria ELECTRE method and destination competitiveness. Tourism Management Perspectives, 6, 108-113. https://doi.org/10.1016/j.tmp.2013.01.001

Cahill, D. (2007). Customer loyalty in third party logistics relationships: findings from studies in Germany and the USA. Heidelberg: Physica-Verlag.

Centobelli, P., Cerchione, R., \& Esposito, E. (2017). Environmental sustainability in the service industry of transportation and logistics service providers: systematic literature review and research directions. Transportation Research Part D: Transport \& Environment, 53, 454-470. https://doi.org/10.1016/j.trd.2017.04.032

Colicchia, C., Marchet, G., Melacini, M., \& Perotti, S. (2013). Building environmental sustainability: Empirical evidence from logistics service providers. Journal of Cleaner Production, 59, 197-209. https://doi.org/10.1016/j.jclepro.2013.06.057 
David, A., \& Damart, S. (2011). Bernard Roy et l'aide multi-critère à la décision. Revue Française de Gestion, 214, 15-28. https://doi.org/10.3166/rfg.214.15-28

De Boer, L., Labro, E., \& Morlacchi, P. (2001). A review of methods supporting supplier selection. European Journal of Purchasing \& Supply Management, 7(2), 75-89. https://doi.org/10.1016/S0969-7012(00)00028-9

Ecer, F. (2018). Third-party logistics (3PLs) provider selection via Fuzzy AHP and EDAS integrated model. Technological \& Economic Development of Economy, 24(2), 615-634. https://doi.org/10.3846/20294913.2016.1213207

Fenies, P. (2011). Une approche pour la prise en compte de la rationalité limitée des acteurs dans les modèles d'aide à la décision: mise en œuvre en contexte de logistique hospitalière. Management \& Avenir, 48, 179-201. https://doi.org/10.3917/mav.048.0179

Figueira, J., Greco, S., Roy, B., \& Słowiński, R. (2013). An overview of ELECTRE methods and their recent extensions. Journal of Multi-Criteria Decision Analysis, 20(1-2), 61-85. https://doi.org/10.1002/mcda.1482

Fulconis, F., Paché, G., \& Roveillo, G. (2011). La prestation logistique: origines, enjeux et perspectives. Caen: Editions Management \& Société.

Fulconis, F., Nollet, J., \& Paché, G. (2016). Purchasing of logistical services: a new view of LSPs' proactive strategies. European Business Review, 28(4), 449-466. https://doi.org/10.1108/EBR-06-2015-0054

Gómez, J.-C., Duque, D., Rivera, L., \& García-Alcaraz, J. (2017). Decision support system for operational risk management in supply chain with 3PL providers. In Alor-Hernández, A., \& Valencia-García, R. (Eds.), Current trends on knowledge-based systems (pp. 205-222). Cham: Springer. https://doi.org/10.1007/978-3-319-51905-0_10

Govindan, K., \& Brandt Jepsen, M. (2016). ELECTRE: a comprehensive literature review on methodologies and application. European Journal of Operational Research, 250(1), 1-29. https://doi.org/10.1016/j.ejor.2015.07.019

Guarnieri, P., Sobreiro, V., Nagano, M., \& Serrano, A. (2015). The challenge of selecting and evaluating third-party reverse logistics providers in a multi-criteria perspective: A Brazilian case. Journal of Cleaner Production, 96, 209-219. https://doi.org/10.1016/j.jclepro.2014.05.040

Haldar, A., Qamaruddin, U., Raut, R., Kharat, M. G., \& Kamble, S. (2017). 3PL evaluation and selection using integrated analytical modelling. Journal of Modelling in Management, 12(2), 224-242. https://doi.org/10.1108/JM2-04-2015-0016

Handley, S., \& Benton Jr, W. (2012). Mediated power and outsourcing relationships. Journal of Operations Management, 30(3), 253-267. https://doi.org/10.1016/j.jom.2011.11.004

Hatami-Marbini, A., \& Tavana, M. (2011). An extension of the ELECTRE I method for group decision-making under a fuzzy environment. Omega, 39(4), 373-386. https://doi.org/10.1016/j.omega.2010.09.001

Haurant, P., Oberti, P., \& Muselli, M. (2011). Multi-criteria selection aiding related to photovoltaic plants on farming fields on Corsica Island: a real case study using the ELECTRE outranking framework. Energy Policy, 39(2), 676-688. https://doi.org/10.1016/j.enpol.2010.10.040

Hofenk, D., Schipper, R., Semeijn, J., \& Gelderman, C. (2011). The influence of contractual and relational factors on the effectiveness of third party logistics relationships. Journal of Purchasing \& Supply Management, 17(3), 167-175. https://doi.org/10.1016/j.pursup.2011.04.003

Hsu, C.-C., Kannan, V.-R., Keong Leong, G., \& Tan, K.-C. (2006). Supplier selection construct: instrument development and validation. International Journal of Logistics Management, 17(2), 213-239. https://doi.org/10.1108/09574090610689961

Ishizaka, A., \& Nemery, P. (2014). Assigning machines to incomparable maintenance strategies with ELECTRE-SORT. Omega, 47(C), 45-59. https://doi.org/10.1016/j.omega.2014.03.006

Jain, V., \& Khan, S. (2017). Application of AHP in reverse logistics service provider selection: A case study. International Journal of Business Innovation \& Research, 12(1), 94-119. https://doi.org/10.1504/IJBIR.2017.080711

Jothimani, D., \& Sarmah, S. (2014). Supply chain performance measurement for third party logistics. Benchmarking: An International Journal, 21(6), 944-963. https://doi.org/10.1108/BIJ-09-2012-0064

Kishore, P., \& Padmanabhan, G. (2016). An integrated approach of Fuzzy AHP and Fuzzy TOPSIS to select logistics service provider. Journal for Manufacturing Science \& Production, 16(1), 51-59. https://doi.org/10.1515/jmsp-2015-0017 
König, A., \& Spinler, S. (2016). The effect of logistics outsourcing on the supply chain vulnerability of shippers: development of a conceptual risk management framework. International Journal of Logistics Management, 27(1), 122-141. https://doi.org/10.1108/IJLM-03-2014-0043

Lai, K., Ngai, E., \& Cheng, T. (2004). An empirical study of supply chain performance in transport logistics. International Journal of Production Economics, 87(2), 321-331. https://doi.org/10.1016/j.ijpe.2003.08.002

Lazzolino, G., Laise, D., \& Marraro, L. (2012). Business multi-criteria performance analysis: A tutorial. Benchmarking: An International Journal, 19(3), 395-411. https://doi.org/10.1108/14635771211243012

Li, F., Li, L., Jin, C., Wing, R., Wing, H., \& Yang, L. (2012). A 3PL supplier selection model based on fuzzy sets. Computers \& Operations Research, 39(8), 1879-1884. https://doi.org/10.1016/j.cor.2011.06.022

Li, Y., Kannan, D., Garg, K., Gupta, S., \& Jha, P.-C. (2018). Business orientation policy and process analysis evaluation for establishing third party providers of reverse logistics services. Journal of Cleaner Production, 182, 1033-1047. https//doi.org/10.1016/j.jclepro.2017.12.241

Lieb, R., \& Bentz, B. (2005). The use of third-party logistics services by large American manufacturers: the 2004 survey. Transportation Journal, 44(2), 5-15. http://www-jstor-org/stable/20713595

Lu, Q., Meng, F., \& Goh, M. (2014). Choice of supply chain governance: self-managing or outsourcing? International Journal of Production Economics, 154, 32-38. https://doi.org/10.1016/j.jpe.2014.03.022

Mahmoudzadeh, M., Mansour, S., \& Karimi, B. (2013). To develop a third-party reverse logistics network for end-of-life vehicles in Iran. Resources, Conservation \& Recycling, 78, 1-14. https://doi.org/10.1016/j.resconrec.2013.06.006

Marchet, G., Melacini, M., Perotti, S., Sassi, C., \& Tappia, E. (2017). Value creation models in the 3PL industry: what 3PL providers do to cope with shipper requirements. International Journal of Physical Distribution \& Logistics Management, 47(6), 472-494. https://doi.org/10.1108/JJPDLM-04-2016-0120

McGinnis, M., Kochunny, C., \& Ackerman, K. (1995). Third party logistics choice. International Journal of Logistics Management, 6(2), 93-102. https://doi.org/10.1108/09574099510805378

Menon, M., McGinnis, M., \& Ackerman, K. (1998). Selection criteria for providers of third-party logistics services: an exploratory study. Journal of Business Logistics, 19(1), 121-137.

Min, H., \& Ko, H.-J. (2008). The dynamic design of a reverse logistics network from the perspective of third-party logistics service providers. International Journal of Production Economics, 113(1), 176-192. https://doi.org/10.1016/j.ijpe.2007.01.017

Mousseau, V., Slowinski, R., \& Zielniewicz, P. (2000). A user-oriented implementation of the ELECTRE-TRI method integrating preference elicitation support. Computers \& Operations Research, 27(7-8), 757-777. https://doi.org/10.1016/S0305-0548(99)00117-3

Muhindo, A., Zhou, J., \& Kapute Mzuza, M. (2014). Impact of logistics outsourcing strategy in oil and gas industry in Uganda. International Journal of Business \& Management, 9(6), 187-198. https://doi.org/10.5539/ijbm.v9n6p187

Mukherjee, K. (2017). Supplier selection: an MCDA-based approach. New Delhi: Springer. https://doi.org/10.1007/978-81-322-3700-6

Pourjavad, E., \& Shirouyehzad, H. (2011). A MCDM approach for prioritizing production lines: a case study. International Journal of Business \& Management, 6(10), 221-229. https://doi.org/10.5539/ijbm.v6n10p221

Raut, R., Kharat, M., Kamble, S., \& Kumar, C.-S (2018). Sustainable evaluation and selection of potential third-party logistics (3PL) providers: an integrated MCDM approach. Benchmarking: An International Journal, 25(1), 76-97. https://doi.org/10.1108/BIJ-05-2016-0065

Ravi, V. (2011). Selection of third-party reverse logistics providers for end-of-life computers using TOPSIS-AHP based approach. International Journal of Logistics Systems \& Management, 11(1), 24-37. https://doi.org/10.1504/IJLSM.2012.044048

Rogers, M., Bruen, M., \& Maystre, L.-Y. (2000). ELECTRE and decision support: methods and applications in engineering and infrastructure investment. Dordrecht: Kluwer Academic Publishers. https://doi.org/10.1007/978-1-4757-5057-7

Roy, B. (1968). Classement et choix en présence de points de vue multiples (la méthode ELECTRE). RAIRO Recherche Opérationnelle-Operations Research, 2(1), 57-75. https://doi.org/10.1051/ro/196802V100571 
Roy, B., \& Vincke, P. (1981). Multi-criteria analysis: survey and new directions. European Journal of Operational Research, 8(3), 207-218. https://doi.org/10.1016/0377-2217(81)90168-5

Saglietto, L., \& Cézanne, C., Eds. (2017). Global intermediation and logistics service providers. Hershey (PA): IGI Global.

Sallnäs, U. (2016). Coordination to manage dependencies between logistics service providers and shippers: an environmental perspective. International Journal of Physical Distribution \& Logistics Management, 46(3), 316-340. https://doi.org/10.1108/IJPDLM-06-2014-0143

Sevkli, M. (2010). An application of the fuzzy ELECTRE method for supply selection. International Journal of Production Research, 48(12), 3393-3405. https://doi.org/10.1080/00207540902814355.

Suyabatmaz, A., Tevhide Altekin, F., \& Şahin, G. (2014). Hybrid simulation-analytical modeling approaches for the reverse logistics network design of a third-party logistics provider. Computers \& Industrial Engineering, 70, 74-89. https://doi.org/10.1016/j.cie.2014.01.004

Tan, A., Yifei, Z., Zhang, D., \& Hilmola, O. H. (2014). State of third party logistics providers in China. Industrial Management \& Data Systems, 114(9), 1322-1343. https://doi.org/10.1108/IMDS-06-2014-0179

Trentin, A. (2011). Third-party logistics providers offering form postponement services: value propositions and organisational approaches. International Journal of Production Research, 49(6), 1685-1712. https://doi.org/10.1080/00207541003623414

Tsai, M., Lai, K., Lloyd, A., \& Lin, H. (2012). The dark side of logistics outsourcing: unraveling the potential risks leading to failed relationships. Transportation Research Part E: Logistics \& Transportation Review, 48(1), 178-189. https://doi.org/10.1016/j.tre.2011.07.003

Vijayvargiya, A., \& Dey, A. K. (2010). An analytical approach for selection of a logistics provider. Management Decision, 48(3), 403-418. https://doi.org/10.1108/00251741011037774

Wallenburg, C. (2009). Innovation in logistics outsourcing relationships: proactive improvement by logistics service providers as a driver of customer loyalty. Journal of Supply Chain Management, 45(2), 75-93. https://doi/10.1111/j.1745-493X.2009.03164.x

Wang, Y., \& Yeo, G.-T. (2018). Intermodal route selection for cargo transportation from Korea to Central Asia by adopting Fuzzy Delphi and Fuzzy ELECTRE I methods. Maritime Policy \& Management, 45(1), 3-18. https://doi.org/10.1080/030888399.2017.1319581

Yayla, A., Oztekin, A., Gumus, A., \& Gunasekaran, A. (2015). A hybrid data analytic methodology for 3PL transportation provider evaluation using fuzzy multi-criteria decision making. International Journal of Production Research, 53(20), 6097-6113. https://doi.org/10.1080/00207543.2015.1022266

Yücel, M., \& Görener, A. (2016). Decision making for company acquisition by ELECTRE method. International Journal of Supply Chain Management, 5(1), 75-83.

Zhang, D., \& Li, S. (2009). Research on an optimization model for logistics nodes system layout and its solution algorithm. International Journal of Business \& Management, 4(11), 38-49. https://doi.org/10.5539/ijbm.v4n11p38

\section{Copyrights}

Copyright for this article is retained by the author(s), with first publication rights granted to the journal.

This is an open-access article distributed under the terms and conditions of the Creative Commons Attribution license (http://creativecommons.org/licenses/by/4.0/). 